\title{
Mechanism of Adrenal Angiotensin II Receptor Changes after Nephrectomy in Rats
}

\author{
JaniCe G. Douglas, with the technical assistance of CARSON WhITE, Department of \\ Medicine, Case Western Reserve University, Cleveland, Ohio 44106
}

A в S T R A C T At $48 \mathrm{~h}$ after bilateral nephrectomy in rats there is a two- to threefold increase in the number of adrenal angiotensin II receptors and a decrease in $K_{d}$ of smooth muscle angiotensin II receptors. These changes have been attributed to the absence of circulating angiotensin II. Serum $\mathrm{K}^{+}$, which increases after nephrectomy may be an important and overlooked modulator. Therefore, the present experiments were designed to assess the role of $\mathrm{K}^{+}$as a regulator of angiotensin II receptors after nephrectomy. Serum $\mathrm{K}^{+}$ was controlled with $\mathrm{Na}$ polystyrene sulfonate (Kayexalate), a resin designed to exchange $\mathrm{Na}^{+}$for $\mathrm{K}^{+}$in the gastrointestinal tract. Acutely nephrectomized rats were divided into two groups: experimental animals received Kayexalate resin every $12 \mathrm{~h}$ for four doses, and controls received Kayexalate exchanged with $\mathrm{KCl}$ in vitro before gavage. There was a significant positive correlation serum $\mathrm{K}^{+}$and aldosterone $(r=0.78, P$ $<0.001)$. Keyexalate maintained a normal serum $\mathrm{K}^{+}$ of $5.9 \pm 0.2 \mathrm{meq} / \mathrm{liter}(n=27)$, aldosterone $25 \pm 3 \mathrm{ng} / \mathrm{dl}$ $(n=27)$ and adrenal receptor concentration of $934 \pm 156$ $\mathrm{fmol} / \mathrm{mg}$ protein $(n=4)$. Control animals had significantly higher serum $\mathrm{K}^{+}$of $10.5 \pm 0.4 \mathrm{meq} / \mathrm{liter}$ $(n=23)$, aldosterone $435 \pm 32(n=23)$, and adrenal receptors of $2726 \pm 235 \mathrm{fmol} / \mathrm{mg}$ protein $(n=4)$. There was a linear relationship between serum $\mathrm{K}^{+}$and number of adrenal receptors $(r=0.87)$. No such relationship was present in uterine smooth muscle. Therefore, these studies demonstrate that $\mathrm{K}^{+}$modulates the number of adrenal but not smooth muscle angiotensin II receptors after nephrectomy. This is the first evidence that potassium modulates angiotensin II receptors independently of changes in angiotensin II blood levels.

Dr. Douglas is the recipient of Public Health Research Career Development Award.

Received for publication 12 September 1980 and in revised form 5 December 1980.

\section{INTRODUCTION}

An increment in angiotensin II receptors is present in rats at $48 \mathrm{~h}$ after bilateral nephrectomy $(1,2)$. These changes have been demonstrated in both adrenal glomerulosa and uterine smooth muscle and have been presumed to occur secondary to the elimination of renin and angiotensin II from the circulation. However, these receptor changes are atypical of what has been demonstrated to accompany other means of manipulating angiotensin II blood levels. Specifically, low sodium intake (which stimulates renin and angiotensin II) and angiotensin II infusion both increase (3-5), whereas high sodium intake decreases the number of adrenal angiotensin II receptors (3). It therefore seems possible that an alternative explanation, such as the change in ionic composition of plasma, might be responsible for the observed receptor changes after nephrectomy. Nephrectomized rats have a rise of serum potassium of 3 meq as early as $10-12 \mathrm{~h}$ after nephrectomy (6). In addition, we have suggested that potassium acts directly on the adrenal glomerulosa during dietary $\mathrm{K}^{+}$-loading to increase angiotensin II receptors (7). The effects of potassium seemed to occur independently of angiotensin II.

In view of these findings, the present studies were undertaken to evaluate the role of potassium on the control of angiotensin II receptors in rats after bilateral nephrectomy. These studies were also designed to evaluate the relationship between serum electrolytes and aldosterone in rats after nephrectomy.

\section{METHODS}

Materials. Synthetic $\left(\mathrm{Asp}^{1} \mathrm{Ile}^{5}\right)$-angiotensin II was obtained from Beckman Instruments, Inc., Spinco Div., Palo Alto, Calif. The $\left.{ }^{[125} \mathrm{I}\right]$ monoiodo-angiotensin II was prepared by New England Nuclear (Boston, Mass.) with a sp act of 800 $1,000 \mu \mathrm{Ci} / \mu \mathrm{g}$. Female Sprague-Dawley rats $(225-250 \mathrm{~g})$ were obtained from Zivic Miller, Pittsburgh, Pa. 
Experimental protocols. Food was withheld from rats for $12 \mathrm{~h}$ before and $48 \mathrm{~h}$ after nephrectomy. During this period they received only distilled-deionized water to drink ad lib. One group of nephrectomized rats received $2 \mathrm{~g} / \mathrm{kg}$ of sodium polystyrene sulfonate (Kayexalate; Winthrop Laboratories, Sterling Drug Co., New York) with $0.7 \mathrm{~g} / \mathrm{kg}$ of sorbitol and $1 \mathrm{~cm}^{3}$ of magnesium citrate by gavage every $12 \mathrm{~h}$ for four doses. The first dose was administered immediately after nephrectomy. Control animals received the same quantity of the resin exchanged in vitro with $167 \mathrm{mg} \mathrm{KCl} / \mathrm{g}$ of Kayexalate. The resin exchanged in vitro was mixed with a similar amount of sorbitol and magnesium citrate and administered at the same intervals. At death, blood was collected by aortic puncture under ether anesthesia for determination of serum electrolytes by flame photometry and aldosterone by radioimmunoassay $(8)$.

Tissue preparation and receptor binding studies. Experiments were conducted such that receptor binding by tissues from Kayexalate-treated animals was compared with the receptor binding in animals treated with resin exchanged in vitro on the same day. Capsules were stripped from pooled rat adrenals collected in medium 199 at $4^{\circ} \mathrm{C}$, homogenized in $20 \mathrm{mM}$ sodium bicarbonate with a Teflonglass homogenizer, and filtered through nylon gauze. This method has been described elsewhere and verified for use with electrolyte-modified diets (3). Subcellular fractions were collected between 10,000 and $100,000 \mathrm{~g}$ for studies of adrenal receptor binding. Smooth muscle receptors were prepared by a modification of the technique of RouzaireDubois et al. (9), described in detail elsewhere (10). Pooled rat uteri were stripped of serosa, minced, homogenized with a Kinematica, PT 10-20 homogenizer (Kinematics Corp., Barrington, Ill.) for $4 \mathrm{~s}$, filtered through nylon gauze and sedimented at 700-20,000 g. The fraction was used for the radioreceptor assay. Incubations for receptor binding were performed in $50 \mathrm{mM}$ Tris $\mathrm{HCl}(\mathrm{pH} 7.4)$ with 5-15 fmol of ${ }^{125} \mathrm{I}$-angiotensin II, $1 \%$ bovine serum albumin, $5 \mathrm{mM}$ dithiothreitol, $120 \mathrm{mM} \mathrm{NaCl}$, and $125-175 \mu \mathrm{g}$ of smooth muscle or $10-30 \mu \mathrm{g}$ of adrenal receptor protein in a final vol of $300 \mu \mathrm{l}$. Varying concentrations of unlabeled angiotensin II between 10 and $0.1 \mathrm{~nm}$ were added to generate full binding-inhibition curves. All binding is reported as specific binding corrected for binding of tracer in the presence of excess unlabeled angiotensin II $(0.3 \mu \mathrm{M})$. Binding studies were performed at $22^{\circ} \mathrm{C}$ for 30 min with smooth muscle and $60 \mathrm{~min}$ with adrenal tissues. Separation of receptorbound angiotensin II was achieved by Millipore filtration (Millipore Corp., Bedford, Mass.) using HAWP $(0.45 \mu \mathrm{m})$ filters. Under these conditions, nonspecific binding represents $<10 \%$ of the total binding in the adrenal glomerulosa and $<40 \%$ of the total binding in smooth muscle. Samples were counted using a Searle gamma-spectrometer with efficiency of $75 \%$ (Searle Radiographics Inc., Des Plaines, Ill.) Binding constants were determined by Scatchard analysis (11). Linear regression analysis used to determine binding constants was considered significant if $r$ exceeded 0.90. Proteins were determined by the method of Lowry et al. (12) as modified by Cuatrecasas (13). Results are reported as means $\pm \mathrm{SE}$ and statistical significance determined using paired Student's $t$ test for comparisons of receptor binding constants and unpaired Student's $t$ test for other comparisons (14).

\section{RESULTS}

Effect of nephrectomy on angiotensin II receptors. At $48 \mathrm{~h}$ after nephrectomy, rats had a significant increase in serum potassium and aldosterone (Table I). After nephrectomy there were 2,341 $\pm 797 \mathrm{fmol}$ of angiotensin II bound per $\mathrm{mg}$ of adrenal protein $(n=10)$ compared to $499 \pm 135, n=10(P<0.05)$ for control sham-operated animals. In uterine smooth muscle, there was no significant change in the number of receptors. However, there was a slight but significantly lower $K_{\mathrm{d}}$ of $1.7 \pm 0.3 \mathrm{nM}(n=4)$ as compared to the control value of $2.4 \pm 0.3 \mathrm{nM}, n=4$, $(P<0.05)$.

Cation-exchange resin administration. When acutely nephrectomized rats were administered $2 \mathrm{~g} / \mathrm{kg}$ of Kayexalate resin by gavage, it was found that serum potassium and aldosterone were at or below normal values. The serum electrolytes and aldosterones of these animals, who were killed $12 \mathrm{~h}$ after the last Kayexalate dosage, are summarized in Table II. Animals receiving Kayexalate had significantly higher serum sodium, lower serum potassium, and lower serum aldosterone than control animals that received resin exchanged in vitro. Logarithmic changes in serum aldosterone were significantly correlated with linear changes in serum potassium (Fig. 1). The resultant regression analysis was: $\log y=0.2 \mathrm{x}+0.39, r=0.78$, $P<0.001$.

Fig. 2 illustrates representative Scatchard plots of

TABLE I

Serum Electrolytes, Aldosterone, and Angiotensin II Receptor Constants at 48 h after Nephrectomy in Rats

\begin{tabular}{|c|c|c|c|c|c|c|}
\hline & \multirow{2}{*}{$\begin{array}{c}\text { Serum } \\
\text { potassium }\end{array}$} & \multirow{2}{*}{$\begin{array}{c}\text { Serum } \\
\text { aldosterone }\end{array}$} & \multicolumn{2}{|c|}{ Adrenal } & \multicolumn{2}{|c|}{ Smooth muscle } \\
\hline & & & Number & $K_{\mathrm{d}}$ & Number & $K_{\mathrm{d}}$ \\
\hline & meq/liter & $n g / 100 \mathrm{ml}$ & fmol/mg protein & $n M$ & fmol/mg protein & $n M$ \\
\hline Sham-operated & $\begin{array}{c}5.3 \pm 0.3 \\
(23)\end{array}$ & $\begin{array}{c}53 \pm 8.6 \\
(12)\end{array}$ & $\begin{array}{c}499 \pm 135 \\
(10)\end{array}$ & $\begin{array}{c}1.3 \pm 0.1 \\
(10)\end{array}$ & $\begin{array}{c}55 \pm 7 \\
(4)\end{array}$ & $\begin{array}{c}2.4 \pm 0.3 \\
(4)\end{array}$ \\
\hline Nephrectomized & $\begin{array}{c}9.3 \pm 0.3 \\
(13)\end{array}$ & $\begin{array}{c}329 \pm 30 \\
(16)\end{array}$ & $\begin{array}{c}2,341 \pm 797 \\
(10)\end{array}$ & $\begin{array}{c}1.6 \pm 0.4 \\
(10)\end{array}$ & $\begin{array}{c}62 \pm 5 \\
(4)\end{array}$ & $\begin{array}{c}1.7 \pm 0.3 \\
(4)\end{array}$ \\
\hline$P$ value & $<0.001$ & $<0.001$ & $<0.05$ & NS & NS & $<0.05$ \\
\hline
\end{tabular}


TABLE II

Kayexalate Effect on Serum Electrolytes and Aldosterone in Nephrectomized Rats

\begin{tabular}{lccc}
\hline & Serum $\mathrm{Na}^{+}$ & Serum $\mathrm{K}^{+}$ & Serum aldosterone \\
\hline & meqlliter & meq lliter & $n \mathrm{ng} / 100 \mathrm{ml}$ \\
Kayexalate $(2 \mathrm{~g} / \mathrm{kg})$ & $138.5 \pm 1.8$ & $5.9 \pm 0.2$ & $25 \pm 3$ \\
& $(28)$ & $(27)$ & $(27)$ \\
Kayexalate exchanged & $130.5 \pm 1.7$ & $10.5 \pm 0.4$ & $435 \pm 32$ \\
in vitro $(2 \mathrm{~g} / \mathrm{kg})$ & $(24)$ & $(23)$ & $(23)$ \\
$P$ value & $<0.005$ & $<0.001$ & $<0.001$ \\
\hline
\end{tabular}

adrenal radioreceptor assays of rats given Kayexalate or resin exchanged in vitro. This dosage prevented the increase in adrenal receptor concentration that usually occurred after nephrectomy. The receptor concentration was $680 \mathrm{fmol} / \mathrm{mg}$ protein in Kayexalatetreated rats contrasted with $2,327 \mathrm{fmol} / \mathrm{mg}$ protein in animals receiving resin exchanged in vitro. $K_{d}$ were not significantly different.

Table III comprises a summary of results from four experiments. There was a significantly lower number of adrenal receptors in Kayexalate-treated rats as compared to control animals receiving resin exchanged in vitro. There was, however, no significant differ-

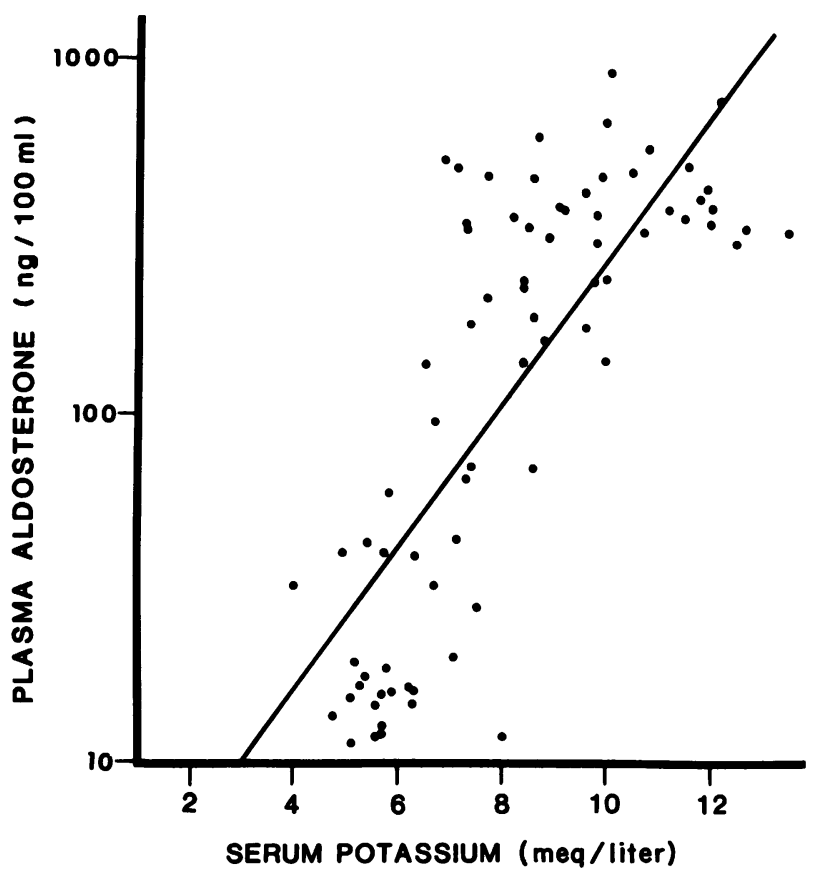

FIGURE 1 Linear regression analysis of semilogarithmic plasma aldosterone and linear serum potassium from nephrectomized rats. Data was collected from two groups of animals: group one received Kayexalate resin exchanged in vitro with $\mathrm{KCl}$ (control) and a second group received Kayexalate resin (experimental). $r=0.78 ; P<0.001$. ence in $K_{d}$ of adrenal and smooth muscle receptors or number of smooth muscle receptors. There was a linear relationship between serum $\mathrm{K}^{+}$and adrenal receptor number with both groups of animals combined (Fig. 3). The resultant regression analysis was $y=0.0023 x+4, r=0.87, P<0.005$. There was no such relationship between the level of serum sodium and number of angiotensin II receptors.

\section{DISCUSSION}

These data demonstrate that there is a direct correlation between the level of serum potassium and the number of adrenal angiotensin II receptors in nephrectomized rats. When serum potassium was prevented from increasing through the use of a cation-exchange resin, the number of adrenal receptors remained at a normal concentration. However, control animals whose serum potassiums were allowed to rise by administering resin exchanged in vitro had significantly higher concentrations of angiotensin II receptors than normal.

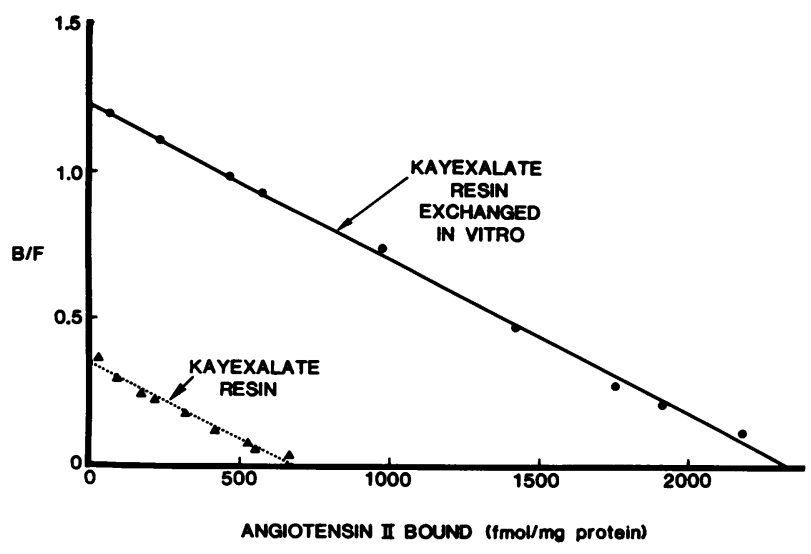

FIGURE 2 Scatchard analysis of adrenal receptor binding of ${ }^{125}$ I-angiotensin II. Values are the mean of triplicate determinations from a single experiment. Adrenal glomerulosa from Kayexalate-treated rats bound $680 \mathrm{fmol} / \mathrm{mg}$ protein with a $K_{\mathrm{d}}$ of $0.64 \mathrm{nM}$ compared with $2,327 \mathrm{fmol} / \mathrm{mg}$ protein with a $K_{d}$ of 0.58 from controls treated with preloaded Kayexalate resin. 
TABLE III

Kayexalate Effect on Angiotensin II Receptors of Nephrectomized Rats

\begin{tabular}{lcccccc}
\hline & \multicolumn{2}{c}{ Adrenal receptors } & & \multicolumn{2}{c}{ Smooth muscle receptors } \\
\cline { 2 - 3 } \cline { 5 - 6 } & Number & $K_{\mathrm{d}}$ & & Number & $K_{\mathrm{d}}$ \\
\hline Kayol/mg protein & $n M$ & & $f$ fmol/mg protein & $n M$ \\
& $934 \pm 156$ & $0.83 \pm 0.07$ & & $95 \pm 19$ & $2.2 \pm 0.2$ \\
Kayexalate exchanged & $(4)$ & $(4)$ & & $(4)$ & $(4)$ \\
in vitro $(2 \mathrm{~g} / \mathrm{kg})$ & $2,726 \pm 235$ & $0.85 \pm 0.1$ & & $66 \pm 17$ & $1.7 \pm 0.5$ \\
$P$ value & $(4)$ & $(4)$ & & $(4)$ & $(4)$ \\
& $<0.01$ & $\mathrm{NS}$ & & $\mathrm{NS}$ & $\mathrm{NS}$ \\
\hline
\end{tabular}

The serum potassium level and receptor concentration of this group of animals was not significantly different from that of animals nephrectomized and given nothing. The cation exchange resin employed primarily exchanged sodium for potassium and as a result the serum sodium was significantly higher in the Kayexalate-treated rats as compared with those receiving the resin exchanged in vitro. Therefore, there was a remote possibility that the serum sodium may have in some way contributed to the receptor changes observed. However, no significant relationship was present between serum sodium and number of angiotensin II receptors.

An increment in serum potassium now seems to be the major factor responsible for the increment in adrenal receptors after nephrectomy $(1,2)$ and with dietary potassium loading $(3,7,10)$. In both of these conditions, there was absent or low renin and angio-

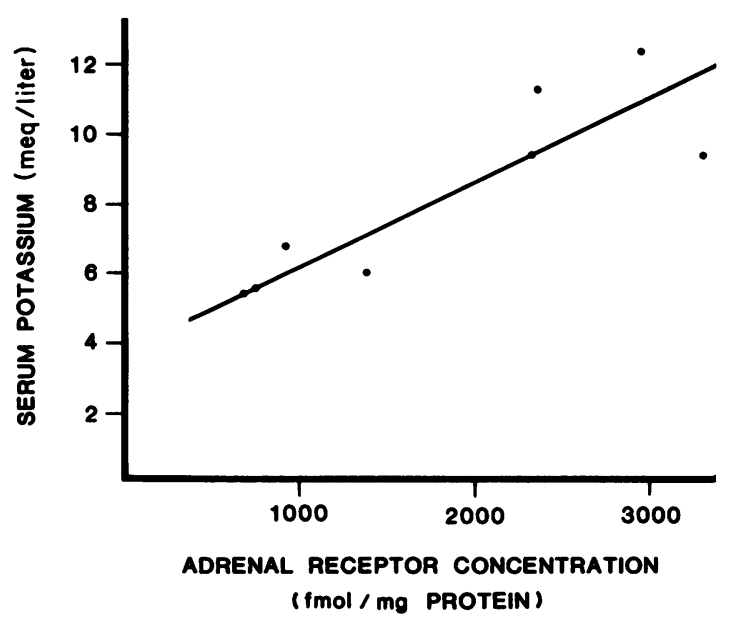

FIGURE 3 Linear regression analysis of serum potassium and adrenal receptor concentration from nephrectomized rats that received either Kayexalate resin exchanged in vitro with $\mathrm{KCl}$ (control) or Kayexalate resin (experimental). $r=0.87, P$ $<0.005$. tensin II, and similar increments in receptors as occurs with the high angiotensin states of sodium depletion (3) and angiotensin infusion (4). In the former situations, potassium was the glomerulotrophic factor that directly stimulated an increment in angiotensin II receptors, independent of angiotensin II. On the other hand, after sodium depletion or angiotensin II infusion, angiotensin served as the major adrenal stimulus for the increment in receptor sites. The changes in adrenal angiotensin II receptors correlated better with the level of serum aldosterone than with the circulating angiotensin II blood level as is illustrated in Fig. 4. With changes in potassium balance or bilateral nephrectomy there was an inverse correlation between the number of adrenal receptors and the level of circulating angiotensin II. In contrast, with changes in sodium balance or angiotensin II infusion, there was a direct correlation between the number of adrenal receptors and the level of circulating angiotensin II. However, one unifying factor in all six states listed in Fig. 4 is that the level of aldosterone varied directly with the number of adrenal receptors. A direct role for mineralocorticoid in the receptor regulatory process is unlikely because deoxycorticosterone acetate administration to rats in a concentration sufficient to cause suppression of renin and hypertension caused a decrease in the number of adrenal angiotensin II receptors (15).

Smooth muscle receptors differed significantly from adrenal receptors in that no correlation was present between the changes in number or affinity of receptor sites and level of serum potassium. Previous studies have demonstrated that angiotensin serves as a major regulator of the number of affinity of uterine smooth muscle receptors (10). The present studies demonstrated a $30 \%$ decrease in the $\boldsymbol{K}_{\mathrm{d}}$ of smooth muscle receptors for angiotensin II after nephrectomy, which correlated with the decrease in one-half the effective dose $\left(E D_{50}\right)$ of angiotensin II of $55 \%$ in uterine myometrium after nephrectomy (16). This receptor 


\begin{tabular}{|c|c|c|c|c|}
\hline & $\begin{array}{l}\text { CIRCULATING } \\
\text { ANGIOTENSIN II }\end{array}$ & $\begin{array}{c}\text { SERUM } \\
K^{+}\end{array}$ & $\begin{array}{c}\text { SERUM } \\
\text { ALDOOSTERONE }\end{array}$ & $\begin{array}{c}\text { ADRENAL } \\
\text { RECEPTORS } \\
\end{array}$ \\
\hline POST-NEPHRECTOMY & & 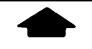 & 4 & 4 \\
\hline POTASSIUM LOADING & $\checkmark$ & 4 & 4 & 4 \\
\hline POTASSIUM DEPLETION & & $\downarrow$ & $\downarrow$ & $\bullet$ \\
\hline ANGIOTENSIN II INFUSION & & $\leftrightarrow$ & 4 & 4 \\
\hline SODIUM DEPLETION & 4 & $\leftrightarrow$ & 4 & 4 \\
\hline SODIUM LOADING & • & $\leftrightarrow$ & $\bullet$ & $\bullet$ \\
\hline
\end{tabular}

Figure 4 Correlations between changes in circulating angiotensin II, serum potassium, aldosterone, and adrenal receptor concentration in rats.

change could in part explain the long-standing observation of enhanced pressor responsiveness to angiotensin II after nephrectomy $(6,17,18)$. Such a comparison between angiotensin II binding properties of uterine smooth muscle and vascular responses to angiotensin II has validity. We have demonstrated excellent correlations between angiotensin II antagonist binding properties in uterine smooth muscle and inhibitory properties in the rat pressor assay and rabbit aortic strip (19). Additionally, alterations in receptor affinity in uterine myometrium accompanying $\mathrm{K}^{+}$-loading in rats correlate with changes in in vivo pressor response to angiotensin II in the rat (20).

The present data are consistent with the interpretation that after nephrectomy, the acute increment of serum potassium caused a logarithmic increase in adrenal sensitivity as measured by aldosterone release. The positive correlation between changes in serum potassium and aldosterone $(r=0.78)$ was greater than the negative correlation between sodium and aldosterone $(r=-0.42)$. Therefore, a role for sodium could not be substantiated. Previous studies in nephrectomized humans (21-24), and animals (25-28) have demonstrated that the adrenal glomerulosa retains the capacity to respond independently to changes in serum potassium and sodium in spite of the absence of renin and angiotensin II. It is of interest that the serum aldosterone of nephrectomized rats with normal serum potassium $(25 \pm 3 \mathrm{ng} / \mathrm{dl}, n=27)$ was lower than rats with kidneys $(53 \pm 8.6 \mathrm{ng} / \mathrm{dl}$, $n=12$ ). Both groups had similar serum potassiums. This suggests that the renin-angiotensin system, acutely stimulated by anesthesia used for blood collection, in rats with kidneys was the major factor responsible for the difference in the two groups.

\section{ACKNOWLEDGMENTS}

The author thanks Ms. Diane Stocker for her expert secretarial work and Dr. J. K. McKenzie for supplying the antisera used for radioimmunoassay of plasma aldosterone.

This investigation was supported by Public Health Service grant HL-22990.

\section{REFERENCES}

1. Devynck, M-A., B. Rouzaire-Dubois, E. Chevillotte, and P. Meyer. 1976. Variations in the number of uterine angiotensin receptors following changes in plasma angiotensin levels. Eur. J. Pharmacol. 40: 27-37.

2. Pernollet, M. G., M. A. Devynck, P. G. Matthews, and P. Meyer. 1977. Post-nephrectomy changes in adrenal angiotensin II receptors in rats; influence of exogenous angiotensin and a competitive antagonist. Eur. J. Pharmacol. 43: 361-372.

3. Douglas, J., and K. J. Catt. 1976. Regulation of angiotensin II receptors in the rat adrenal cortex by dietary electrolytes. J. Clin. Invest. 58: 834-843.

4. Hauger, R. L., G. Aguilera, and K. J. Catt. 1978. Angiotensin II regulates its receptor sites in the adrenal glomerulosa. Nature (Lond.) 271: 176-178.

5. Devynck, M. A., M. G. Pernollet, P. G. Matthews, G. J. MacDonald, R. S. Raisman, and P. Meyer. 1979. Sodium intake and plasma angiotensin level as modulators of adrenal and uterine angiotensin II receptors in rats. J. Cardiovasc. Pharmacol. 1: 163-179.

6. Stouder, D. A., and R. L. Wathen. 1972. Augmented vascular response of the nephrectomized rat to angiotensin. Proc. Soc. Exp. Biol. Med. 141: 548-551.

7. Douglas, J. 1980. Potassium ion as a regulator of adrenal angiotensin II receptors. Am. J. Physiol. 239(2): E317E321.

8. MacKenzie, J. K., and J. A. Clements. 1974. Simplified radioimmunoassay for serum aldosterone utilizing increased antibody specificity. J. Clin. Endocrinol. Metab. 38: $622-627$.

9. Rouzaire-Dubois, B., M-A. Devynck, E. Chevillotte, and P. Meyer. 1975. Angiotensin receptors in rat uterine membranes. FEBS (Fed. Eur. Biochem. Soc.) Lett. 55: 168-172.

10. Douglas, J. G. 1979. Changes in potassium balance: inverse relationship between number and affinity of angiotensin II receptors of smooth muscle and adrenal target tissues. Am. J. Physiol. 237(6): E519-E523.

11. Scatchard, G. 1949. The attractions of proteins for small molecules and ions. Annals N. Y. Acad. Sci. 51: 660-672.

12. Lowry, A. H., N. J. Rosebrough, A. L. Farr, and R. J. Randall. 1951. Protein measurements with the folin phenol reagent. J. Biol. Chem. 193: 265-275.

13. Cuatrecasas, P. 1972. Properties of the insulin receptor isolated from liver and fat cell membranes. J. Biol. Chem. 247: 1980-1991.

14. Colton, T. 1974. Statistics in Medicine. Little, Brown \& Co., Boston, Mass. 131-133.

15. Devynck, M-A., M. G. Pernollet, P. G. Matthews, G. J. 
Macdonald, R. S. Raisman, and P. Meyer. 1979. Sodium intake and plasma angiotensin level as modulators of adrenal and uterine angiotensin II receptors in the rat. J. Cardiovasc. Pharmacol. 1: 163-179.

16. Meyer, P., A. Papadimitriou, and M. Worcel. 1974. Specific supersensitivity of smooth muscle to angiotensin II after nephrectomy. Br. J. Pharmacol. 51: 435-439.

17. Page, I. H., and O. M. Helmer. 1940. Angiotoninactivator, renin- and angiotonin-inhibitor, and the mechanism of angiotonin tachyphylaxis in normal, hypertensive, and nephrectomized animals. J. Exp. Med. 71: 495519.

18. Blaquier, P., S. W. Hoobler, J. Schroeder, A. Gomez, and T. Kreulen. 1962. Effect of bilateral nephrectomy on pressor response to renin. Am. J. Physiol. 203: 339-343.

19. Douglas, J. G., M. Michailov, M. C. Khosla, and F. M. Bumpus. 1980. Comparative receptor binding properties of heptapeptide and octapeptide antagonists of angiotensin II in rat adrenal glomerulosa and uterine smooth muscle. Endocrinology. 106: 120-124.

20. Douglas, J. G. 1979. Changes in potassium balance: inverse relationship between number and affinity of angiotensin II receptors of smooth muscle and adrenal target tissues. Am. J. Physiol. 237: E519-E523.

21. Bayard, R., C. R. Cooke, D. J. Tiller, I. Z. Beitins, A. Kowarski, W. G. Walker, and C. J. Migeon. 1971. Regulation of aldosterone secretion in anephric man. $J$. Clin. Invest. 50: 1585-1595.
22. Mitra, S., S. M. Genuth, L. G. Berman, and V. Vertes. 1972. Aldosterone secretion in anephric patients. N. Engl. J. Med. 286: 61-64.

23. McCaa, R. E., C. S. McCaa, D. G. Read, J. D. Bower, and A. C. Guyton. 1972. Increased plasma aldosterone concentration in response to hemodialysis in nephrectomized man. Circ. Res. 31: 473-480.

24. Read, V. H., C. S. McCaa, J. S. Bower, and R. E. McCaa. 1973. Effect of hemodialysis on the metabolic clearance rate, plasma concentration and blood production rate of aldosterone in anephric man. J. Clin. Endocrinol. Metab. 36: $773-783$.

25. Davis, J. O., J. Urquhart, and J. T. Higgins. 1963. The effects of alterations of plasma sodium and potassium concentration on aldosterone secretion. J. Clin. Invest. 42: $597-609$.

26. Davis, W. W., L. Burwell, and F. C. Bartter. 1969. Inhibition of the effects of angiotensin II on adrenal steroid production by dietary sodium. Proc. Natl. Acad. Sci. U.S.A. 63: 718-723.

27. Palmore, W. P., N. J. Marief, and P. J. Mulrow. 1969. Stimulation of aldosterone secretion by sodium depletion in nephrectomized rats. Endocrinology. 84: 13421351.

28. McCaa, R. E., C. E. Ott, and C. S. McCaa. 1974. Relation between plasma potassium concentration and aldosterone secretion in nephrectomized dogs. Journal of the International Research Communications System. 2: No. 1263. 